\section{Theory of evolution}

\section{Huxley speaks up}

Sir Andrew Huxley, his grandfather's grandson, startled the Anniversary Meeting of the Royal Society this week with a stout defence of the theory of evolution. Traditionally, presidents have used these occasions for making gentle complaints about the British government's handling of science and education. But Huxley, starting with Sir Edmund Leach's statement at the British Association meeting this year (see Nature 3 September, p.19) that many of Wilberforce's nineteenth century criticisms of Darwin were now accepted, said "here is a Huxley answering the challenge"'.

The correspondence in the past twelve months about cladistics and the British Museum (Natural History) still seems to rankle. In defence of cladistics, Huxley said that even the insistence of "transformed cladists" that taxonomic classifications should be made without reference to "necessarily conjectural" ideas about evolutionary processes and

\section{University problems}

Among the points in the secular part of Sir Andrew Huxley's anniversary address on Monday were the following: - The dual support system for academic research, "a shadow of what it used to be", is in danger of being totally obliterated.

- Although the British government had agreed in its expenditure white paper in March to protect basic research, research councils are having to spend more on making good deficiencies of university budgets and are thus less able to support new research projects.

- There is a danger that universities will respond to this summer's budget cuts by further reductions of support for their own research.

- If a university "shows that it is moving in the right direction", the British government should be prepared to reduce the speed or the severity with which cuts are required.

- On the increased fees for overseas students, "I wish to add my voice to the many who have expressed dismay at this drop in our contribution to development, and at the loss of goodwill towards Britain that this policy will entail in the long run".

The society's annual report, also published this week, records that its own subvention from the British government increased to $£ 4.2$ million in the year just ended, from $£ 3.7$ million the previous year. General administration cost $£ 564,000$ - the rest was spent on support for people, international exchanges, grants for research and on international subscriptions. selective pressures "is in no sense a denial of evolution".

Huxley said that his reaction to the correspondence in Nature had been to wonder whether he should "take up the cudgels on Darwin's behalf", but that he had been "mollified" by a "very sensible editorial article" in Nature (30 July, p.395). His concern now was to counter the "ripples [which] continue to spread"'.

In passing, Huxley said that the calculations of Hoyle and Wickramasinghe (see Nature 12 November, p.105) suggesting that there could not have been enough time since the origin of the Universe for life to have evolved could be "dismissed quickly". He said that the characteristic large number used by the authors $\left(10^{40.000}\right)$ represents the chance that 2,000 enzyme molecules would be formed simultaneously "on a single specified occasion". "Since we know neither the nature of the hypothetical self-replicating system nor the composition of the primaeval soup", the conclusion is, however, "wildly uncertain".

It is unlikely that Hoyle and Wickramasinghe will accept their dismissal on these grounds. Their arguments are based on the "information content" of the evolved genome, and on estimates of the rate at which information content might plausibly accumulate.

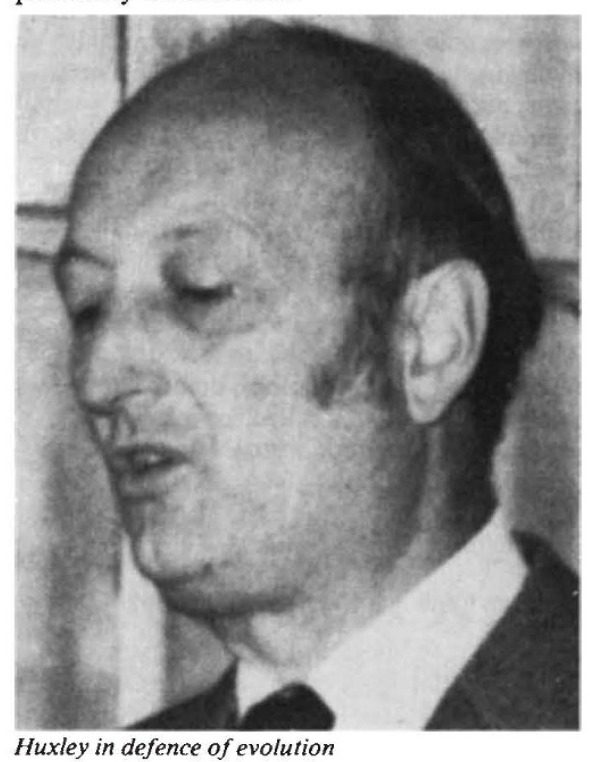

On the doctrine of Gould and Eldridge of punctuated equilibria, Huxley said that the debate lies within the Darwinian framework but that its authors have exaggerated the suddenness with which new stable species emerge. In any case, he said, Darwin's own guess that it would take ten or a hundred thousand generations for two "well-formed" species to emerge from a single species is not inconsistent with the doctrine of punctuated equilibria, while later editions of The Origin of Species, like the writings of neo-Darwinians such as G.G. Simpson, contain statements which are "exactly equivalent" to punctuated equilibria. In the circumstances, Huxley said, he could not understand how

\section{Rhesus monkeys die}

The University of Birmingham is being forced by financial and legal circumstances to kill most of its once thriving monkey colony.

Unable to raise the $£ 250,000$ needed to bring its monkey housing up to present safety standards, the university has for the past two years been exploring the possibility of dispersing all the animals elsewhere. Although there is no shortage of willing recipients, the university has finally decided that the probable legal risks in dispersing its adult monkeys are too great to delay any longer what they see as the almost inevitable slaughter of the animals.

The legal difficulties arise because almost all the adult rhesus monkeys have been used for experimental purposes under Certificate $B$ of the Prevention of Cruelty to Animals Act which demands that animals be killed at the end of an experiment. Many experiments on the Birmingham monkeys were in midstream when they were stopped by the university pending modernization of the housing.

Since the experiments were interrupted rather than finished, it has been argued that the monkeys could be transferred elsewhere and experimentation continued. But the university, in consultation with the Home Office, has decided that it would be too risky to test that interpretation of the law.

Peter Newmark

punctuated equilibria could be regarded as contrary either to Darwin's own ideas or to those of neo-Darwinism.

On Sir Edmund Leach's echo of Wilberforce's complaint that the fossil record lacks evidence of the "missing links" between major stable groups of species, Huxley replied with a list of "missing links" whose discovery "has gone on at an increasing rate since before the publication of The Origin of Species to the present day", such as Archaeopteryx (1861), the fossil horses and hominids more ancient than the Neanderthals.

Huxley went on to dismiss other complaints made by Wilberforce and Owen a century ago, chiding anti-evolutionists for overlooking the "positive indications" from biochemistry, which have demonstrated the "ubiquity of the main metabolic pathways" and of Mendelian inheritance - "precisely what Darwin needed".

Likening the present status of evolution to that of biochemistry fifty years ago, Huxley listed the remaining "gaps" that seem to him important - the absence of evidence for the origin of the major groups of animals in the Palaeozoic, the inheritance of interspecific sterility, the role of genetic drift, the origin of life and the existence of consciousness - "too often swept under the carpet". 